\title{
Efektifitas Incenerator Untuk Pembakaran Sampah Medis di RSUD Kota ABC
}

\author{
Hasti Suprihatin \\ Prodi Teknik Lingkungan, Fakultas Teknik Sipil dan Perencanaan, Institut Teknologi Pembangunan Surabaya \\ Jalan Balongsari Praja V/1 Surabaya, Telp (031) 7406783 \\ e-mail: hasti.suprihatin@yahoo.com
}

\begin{abstract}
To reduce the number of germic or nosocomial infections, especially come from waste disposal. Especially for hospitals, the disposal procedure should cut off the chain of transmission or the spread of disease which are came from the clinical waste or medical waste by burning the clinical waste or medical waste using the incinerator.

Incenerator is used with high temperature by $800^{\circ} \mathrm{C}$. Incenerator has been proven to reduce medical waste about $70 \%$ to $90 \%$, but it can also reduce the number of pathogenic bacteria to zero in percentage. In the using of incinerators, there has not been an assessment of the effectiveness of incinerator usage until today.

Research method which has been used is analytical research to determine the effectiveness of incinerator usage due to the destruction of the medical waste. The result of examination about effectivity of incinerator usage for 4 times of combustion was obtained that the burning volume of medical waste exceeding the required incenerator volume of $0.7 \mathrm{~m}^{3} /$ day is very ineffective with the burning time for 2 hours, because of the results of the research with different volume shows that the volume of $0.7 \mathrm{~m}^{3}$ is an effective volume for incinerators in Public Hospital of ABC City, this is being streghtened based on the results of hypothesis testing that shows the volume of $0.7 \mathrm{~m}^{3}$ would be more effective volume and could give a significant result. In fact, the medical waste should be burnt twice a day in order to be able to burn all the medical waste which is generated.
\end{abstract}

\section{Key words: Effectiveness, Incenerator, Medical Waste}

Rumah Sakit adalah suatu institusi atau lembaga yang menyelenggarakan atau memberikan pelayanan kesehatan kepada perorangan, keluarga dan masyarakat, dengan pelayanan medis yang meliputi upaya promotif, preventif, kuratif maupun rehabilitative yang diselenggarakan secara terpadu dan berkesinambungan.

Rumah Sakit merupakan penghasil limbah dari sampah medis yang sangat besar. Berbagai jenis limbah dari sampah medis yang dihasilkan di Rumah Sakit dan unit-unit pelayanan kesehatan masyarakat, yang dapat membahayakan dan menimbulkan gangguan kesehatan baik bagi pengunjung, karyawan dan utamanya bagi petugas yang menangani limbah dari sampah medis tersebut serta lingkungannya. (UU nomor 36 tahun 2009, UU nomor 18 tahun 2008 dan Peraturan Menteri Negara Lingkungan Hidup nomor 32 tahun 2009).
Limbah Rumah Sakit dapat dianggap sebagai mata rantai penularan dan penyebaran penyakit menular, karena sampah bisa menjadi tempat tertimbunnya mikroorganisme pathogen penyebab infeksi dan penyakit.

Sampah medis juga mengandung benda yang membahayakan dan menimbulkan gangguan kesehatan maupun cidera jika tidak mendapatkan penanganan dan pengelolaan.

Mengurangi sampah medis Rumah Sakit, maka diperlukan system pemusnahan yang baik, efektif dan efisien.Yaitu dengan cara pembakaran pada suhu tinggi dalam tungku incinerator (Incenerasi). Karena dengan pembakaran tersebut disamping dapat membunuh mikroorganisme pathogen, juga dapat mengurangi volume sampah medis hingga menjadi sisa abu yang sudah aman untuk dibuang ke tempat pembuangan sampah akhir atau TPA. Penggunaan incinerator di Rumah Sakit merupakan salah satu system pengolahan 
limbah yang aman bagi kesehatan manusia maupun lingkungan hidup sekitarnya ( UU RI, No.32 Tahun 2009 ). Rumah Sakit Umum Daerah Kota ABC di dalam penggunaan incinerator selama ini belum pernah dilakukan pendataan mengenai hasil timbulan atau volume dari sampah medis, dihubungkan dengan daya tampung incinerator, volume sisa sampah medis yang belum terbakar habis, serta data tentang berat sisa hasil pembakaran (abu). Tetapi keadaan incenerator saat ini menunjukkan bahwa penggunaannya kurang efektif dalam pembakaran sampah medis yang dihasilkan oleh Rumah Sakit dan Puskesmas wilayah Kota ABC. Dengan demikian harapannya kedepan Rumah Sakit ini mampu memberikan pelayanan yang lebih baik, professional dan bermutu dengan biaya pengobatan dan perawatan yang terjangkau sesuai VISI dan MISI. Dalam penelitian yang lain disimpulkan semakin tinggi suhu pembakaran maka proses pembakaran akan semakin baik karena terpenuhinya nilai kalor untuk proses pengabuan dan semakin lama waktu pembakaran maka kemampuan penyisihan residu juga bertambah (Rahayu Dwi Utami, D.G Okayadnya dan M. Mirwan,2012)

Tujuan Penelitian : untuk mengetahui volume sampah medis rata-rata perhari yang efektif digunakan Incenerator di RSUD Kota $\mathrm{ABC}$, untuk mengetahui hasil pembakaran $10 \%$ sampai dengan $30 \%$ sesuai dengan tipe incinerator yang digunakan.

Manfaat Penelitian dapat digunakan sebagai bahan masukan Rumah Sakit di dalam mengambil kebijakan khususnya dalam upaya penanganan sampah medis dengan menggunakan incinerator dan dapat digunakan sebagai bahan pertimbangan maupun acuan pada penelitian yang akan datang khususnya mengenai incinerator.

Incenerator adalah suatu alat yang dipergunakan untuk proses pengurangan atau perubahan bentuk sampah yang sudah terbakar menjadi abu pada suhu yang tinggi. Incenerator merupakan suatu alat berupa tungku pembakaran yang bersuhu tinggi $\left(\Rightarrow 1000^{\circ} \mathrm{C}\right)$, yang digunakan untuk memusnahkan sampah infeksius, ataupun sampah bahan berbahaya dan beracun. Incinerasi adalah sebuah proses pembakaran yang memungkinkan materi yang mudah terbakar seperti hanya limbah organik mengalami pembakaran, hasil pembakaran berupa residu materi yang sulit terbakar dan abu serta gas atau partikulat. Residu serta abu yang dihasilkan dikeluarkan dari incinerator dan ditimbun dilahan yang rendah, sedangkan gas atau partikulat dikeluarkan melalui cerobong setelah sarana pengolah pencemar udara yang sesuai (Reinhardt \& JG. Gordon, 1995 : 77.) Hasil pengurangan volume dan massa juga mengurangi sifat berbahaya dari limbah tersebut manakala limbah tersebut adalah limbah yang berbahaya dan beracun, dan kemudian yang sangat memegang peranan penting dalam hal ini adalah temperatur dan waktu tinggal yang sesuai selama waktu pembakaran limbah berbahaya tersebut. Teknologi incenerasi merupakan salah satu cara pengolahan yang baik bagi materi yang mudah terbakar yang mempunyai nilai kalori yang memadai. Limbah berbahaya yang patogenik, seperti dari rumah sakit terutama untuk limbah medis yang berkategorikan infeksius, sangat baik ditangani cara ini. Mikroorganisme pathogen dalam limbah infeksius dapat dimusnahkan disebuah incinerator yang baik karena adanya panas yang tinggi. Waktu tinggal limbah serta temperatur operasi merupakan parameter penentu dalam keberhasilan proses incenerasi limbah medis. Beberapa hal yang perlu diperhatkan apabila incenerator akan digunakan di rumah sakit antar lain ialah : ukuran, desain kapasitas yang disesuaikan dengan volume sampah medis yang akan dibakar dan disesuaikan pula dengan pengaturan pengendalian pencemaran udara, penempatan lokasi yang berkaitan dengan jalur pengangkutan sampah dalam kompleks rumah sakit dan jalur pembuangan abu, serta perangkap untuk melindungi incenerator dari bahaya kebakaran.(Reinhardt \& JG. Gordon, $1995: 110$ )

Limbah Klinis adalah limbah yang berasal dari pelayanan medis, perawatan gigi, “ veterinary ",farmasi atau yang sejenis, ( penelitian, pengobatan, perawatan atau pendidikan ) yang menggunakan bahan-bahan yang beracun, infeksius, berbahaya atau bisa membahayakan, kecuali jika dilakukan pengamanan tertentu. Sampah Rumah Sakit adalah bahan yang tidak berguna, tidak digunakan ataupun yang terbuang yang dapat dibedakan menjadi sampah medis dan non medis, dan dikategorikan : sampah radioaktif, 
sampah infeksius, sampah citotoksik dan sampah umum ( domestic ).

\section{Ukuran Berat/ Volume}

1. APHA (American Public Health Association), merekomendasikan, bahwa kuantitas sampah combustible (yang bisa terbakar) adalah : 4,85 $\mathrm{lb} / \mathrm{ft}^{3}=77,7455$ $\mathrm{kg} / \mathrm{m}^{3}$, dimana $1 \mathrm{lb}=0,4536 \mathrm{~kg}$ dan $1 \mathrm{ft}^{3}=$ $0,02832 \mathrm{~m}^{3}$.

2. WHO mengemukakan bahwa kepadatan sampah berkisar antara $100-500 \mathrm{~kg} / \mathrm{m}^{3}$, dengan 0,2-0,3 $\mathrm{kg}$ kapasitas perhari.

Rumus umum yang digunakan untuk menghitung efisiensi adalah :

Dimana :

$$
\mathrm{E}(\%)=\left(\underline{\mathrm{V}}_{0}-\mathrm{V}_{1}\right) \times 100 \%
$$

\section{$\mathrm{E}=$ Efisiensi}

$\mathrm{V}_{0}=$ Sampah medis sebelum dimusnahkan

$\mathrm{V}_{1}=$ Sampah medis setelah dimusnahkan

\section{Mikroba dan Suhu Pertumbuhan}

1. Suhu pertumbuhan mikroba

Tabel 1. Rentang suhu pertumbuhan mikroba

\begin{tabular}{lccc}
\hline \multicolumn{1}{c}{ Grup } & \multicolumn{3}{c}{ Suhu Pertumbuhan $\left({ }^{\circ} \mathbf{C}\right)$} \\
\cline { 2 - 4 } & $\begin{array}{c}\text { Minimu } \\
\mathrm{m}\end{array}$ & Optimum & $\begin{array}{c}\text { Maksimu } \\
\mathrm{m}\end{array}$ \\
Psikrofil & $5-10$ & $5-15$ & $15-20$ \\
Misofil & $10-20$ & $20-40$ & $40-45$ \\
Termofil & $25-45$ & $45-60$ & $60-80$
\end{tabular}

Sumber : Lucia W Muslimin, Mikrobiologi Lingkungan, Jakarta Ditjen Dikti Depdikbud 1995

2. Suhu Pematian

Tabel 2.Perkiraan suhu mematikan pada mikroba yang berbeda

\begin{tabular}{lc}
\hline \multicolumn{1}{c}{ Mikroba } & Suhu \\
\hline & \\
Protozoa & $45-50$ \\
Ganggang Eukariot & 56 \\
Fungi & 60 \\
Bakteri Fotosintetik/ Cyanobakter & $70-73$ \\
Bakteri lainnya & 99
\end{tabular}

Sumber : Lucia W Muslimin, Mikrobiologi Lingkungan, Jakarta Ditjen Dikti Depdikbud 1995, hal 53

Pada kondisi asam dengan suhu $80^{\circ} \mathrm{C}$, bakteri masih dapat hidup, sedangkan suasana basa, paling tinggi masih dapat hidup pada suhu $90^{\circ} \mathrm{C}$

3. Suhu dan Waktu pertumbuhan Spora

Tabel 3. Suhu Pembunuhan Spora dalam menit

\begin{tabular}{ccccccc}
\hline${ }^{\circ} \mathbf{C}$ & $\mathbf{1 1 6}$ & $\mathbf{1 1 6}$ & $\mathbf{1 2 1}$ & $\mathbf{1 2 5}$ & $\mathbf{1 3 2}$ & $\mathbf{1 3 8}$ \\
\hline${ }^{\circ} \mathbf{F}$ & 240 & 245 & 250 & 257 & 270 & 280 \\
Menit & 30 & 18 & 12 & 8 & 2 & 0,8
\end{tabular}

Proses Pemusnahan Sampah Organik (Infeksius) Di Dalam Incenerator

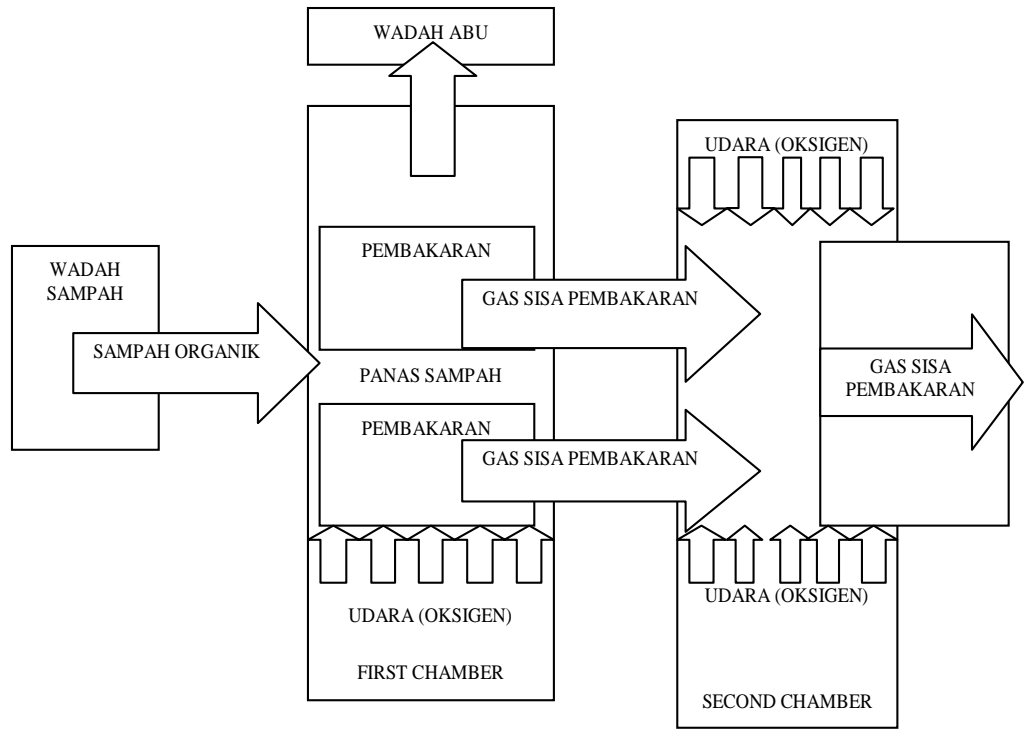

Gambar 1. Proses pemusnahan sampah organik (infeksius) di dalam incinerator 
Incenerator terdiri dari dua ruang, First Chamber dan Second Chamber. Di dalam First Chamber diupayakan terjadi pilorisa. Ke dalam First Chamber disuplaikan $30 \%$ sampai dengan $60 \%$ oksigen stoikiometrik. Oksigen tersebut digunakan untuk melangsungkan pembakaran sehingga temperature pirolisa dipertahankan.

Gas - gas hasil pilorisa selanjutnya dibakar sempurna di Second Chamber. Dengan pencampuran oksigen, metana, etana dan karbonmonoksida diuraikan menjadi Air ( Gas ) dan Karbodioksida. Hasil pembakaran di Second Chamber sangat ditentukan oleh kuantitas oksigen dan kualitas pencampurannya.

\section{Proses Kerja Incenerator}

Sampah dimasukkan ke dalam First Chamber melalui Charging Door, dipanaskan oleh satu buah burner yaitu $\mathbf{1}^{\text {st }}$ Burner. Temperatur di dalam First Chamber yang lebih tinggi dari titik bakar sampah serta adanya oksigen untuk melangsungkan pembakaran yang disuplai oleh FDF Blower menyebabkan sampah padat terbakar, terurai menjadi gas dan abu serta padatan tak terbakar. Abu di ruang bakar yang terjadi selanjutnya dibuang secara berkala setelah First Chamber dingin. Pada saat temperature First Chamber telah cukup tinggi (sesuai setting), sampah telah terbakar, 1 st Burner akan mati secara otomatis untuk menghemat bahan bakar suplemen. Gas hasil pembakaran sampah di First Chamber dialirkan ke Second Chamber untuk dibakar dengan bantuan $2^{\text {nd }}$ Burner. Hasil pembakaran di Second Chamber ialah gas - gas yang telah terbakar sempurna (terutama $\mathrm{CO} 2$ dan $\mathrm{H} 2 \mathrm{O}$ ).

Pada saat pengoperasian incinerator, sebaiknya temperature First Chamber dipertahankan antara $600^{\circ} \mathrm{C}-950^{\circ} \mathrm{C}($ temperature pirolisa ). Dengan menjaga suhu pada temperature tersebut suplai BBM dapat dihemat, temperature pada Second Chamber dapat ditingkatkan, serta usia pemakaian alat dapat lebih lama.

\section{BAHAN DAN METODE}

\section{Metode Studi}

Penelitian ini bersifat diskriptif dan analitik yaitu ingin mengetahui efektifitas pembakaran sampah medis dengan menggunakan incinerator

Populasi pada penelitian ini adalah : Sampahmedis yang dihasilkan Rumah Sakit Umum Daerah Kota ABC dan Puskesmas wilayah Kota ABC. Sampel penelitian adalah sebagian sampah medis yang diproses pada incinerator yang merupakan alat pembakar / pemusnah sampah medis yang ada di RSUD Kota ABC.

\section{Metode Pengumpulan Data}

1. Metode Observasi: sumber timbulan sampah medis, jenis-jenis sampah medis yang dihasilkan, proses pembakaran pada incinerator.

2. Metode pengukuran, mengukur tentang : berat volume masing-masing jenis sampah medis, volume incinerator untuk sekali pembakaran, berat volume sisa pembakaran sampah medis yang tidak bisa hancur / lebur sempurna dan hasil pembakaran ( $a b u$ ).

\section{Metode Analisis Data}

Rumus umum yang digunakan untuk menghitung efisiensi adalah :

$$
E(\%)=\frac{\left(V_{0}-V_{1}\right)}{V_{0}} \times 100 \%
$$

Dimana :

$$
\begin{aligned}
& \mathrm{E}=\text { Efisiensi pembakaran dengan } \\
& \text { Incinerator } \\
& \mathrm{V}_{\mathrm{O}} \quad \begin{array}{l}
\text { Volume sampah medis sebelum } \\
\text { dibakar }
\end{array} \\
& \mathrm{V}_{1} \quad \begin{array}{l}
= \\
\text { Volume sampah medis setelah } \\
\text { dibakar }
\end{array}
\end{aligned}
$$

Teknik pengukuran jumlah dan berat limbah : Untuk incenerasi pengurangan berat limbah / sampah medis, yaitu antara 70 sampai dengan $90 \%$ atau dengan kata lain penyisaan volume sisa bakar sampah medis dari incenerator adalah berkisar antara $10 \%$ sampai dengan $30 \%$. Selain menggunakan hasil pengukuran yang dilakukan untuk mengetahui apakah 
pengukuran tersebut signifikan atau tidak maka dilakukan dengan uji hipotesis untuk mengetahui hubungan antara volume sampah yang dibakar dengan kapasitas incinerator terkait efektifitas penggunaan incinerator yang disyaratkan, yaitu dengan Hipotesa Nihil dan Hipotesa Alternatip dengan menggunakan Rumus sebagai berikut:

$\begin{aligned} \text { Dimana : } \quad & \mathrm{t}=\frac{\mathrm{X}-\mu}{\mathrm{S} / \sqrt{\mathrm{n}}} \\ & \mathrm{S}=\frac{\mathrm{V} \mathrm{n}}{\mathrm{n}} \\ & \text { Ho }: \mu=\mu \mathrm{o} \\ & \text { Ho }: \mu \neq \mu \mathrm{o} \\ & \text { Ho diterima apabila : } \\ & -\mathrm{t}(\alpha / 2, \mathrm{n}-1) \leq \mathrm{t} \leq \mathrm{t}(\alpha / 2, \mathrm{n}-1) \\ & \text { Ho ditolak apabila : } \\ & \mathrm{t}>\mathrm{t}{ }_{(\alpha / 2, \mathrm{n}-1)} \text { atau } \mathrm{t}<-\mathrm{t}(\alpha / 2, \mathrm{n}-1)\end{aligned}$

\section{HASIL}

Limbah yang diteliti adalah limbah dari RSUD ABC dan 6 Puskesmas. Pengukuran volume timbulan sampah medis dilakukan di lapangan (TPS-RS) selama 10 (sepuluh) hari, yang telah dikumpulkan oleh petugas dari ruangan, pada kantong sampahnya diberi label nama - nama ruangan, dan setelah sampai di tempat pembuangan sementara Rumah Sakit sebelum dilakukan pembakaran di incinerator, sampah tersebut ditimbang terlebih dahulu, setelah diketahui berat seluruhnya barulah dipilah - pilah kemudian ditimbang lagi sesuai dengan jenisnya masing - masing . Dari hasil pengukuran diperoleh data volume timbulan sampah medis seperti tertera pada tabel 4 berikut ini :

Tabel 4. Hasil Pengukuran Berat Dan Volume Sampah Medis Perhari Di Rumah Sakit Umum Daerah Kota Abc Dan Puskesmas Wilayah Kota Abc

\begin{tabular}{|c|c|c|c|c|c|c|c|c|c|c|c|c|c|}
\hline \multirow[t]{2}{*}{ No } & \multirow[t]{2}{*}{ Asal } & \multicolumn{2}{|c|}{ Hari ke 7} & \multicolumn{2}{|c|}{ Hari ke 8} & \multicolumn{2}{|c|}{ Hari ke 9} & \multicolumn{2}{|c|}{ Hari ke 10} & \multirow{2}{*}{$\begin{array}{l}\text { Total } \\
\text { Berat }\end{array}$} & \multirow{2}{*}{$\begin{array}{l}\text { Rata2 } \\
\text { Berat }\end{array}$} & \multirow{2}{*}{$\begin{array}{c}\text { Total } \\
\text { Volume }\end{array}$} & \multirow{2}{*}{$\begin{array}{c}\text { Rata2 } \\
\text { Volum } \\
\mathrm{e} \\
\left(\mathrm{m}^{3}\right)\end{array}$} \\
\hline & & $\begin{array}{l}\text { Berat } \\
(\mathrm{Kg})\end{array}$ & $\begin{array}{l}\text { Volume } \\
\left(\mathrm{m}^{3}\right)\end{array}$ & $\begin{array}{l}\text { Berat } \\
(\mathrm{Kg})\end{array}$ & $\begin{array}{c}\text { Volume } \\
\quad\left(\mathrm{m}^{3}\right)\end{array}$ & $\begin{array}{l}\text { Berat } \\
(\mathrm{Kg})\end{array}$ & $\begin{array}{l}\text { Volume } \\
\left(\mathrm{m}^{3}\right)\end{array}$ & $\begin{array}{l}\text { Berat } \\
(\mathrm{Kg})\end{array}$ & $\begin{array}{c}\text { Volume } \\
\left(\mathrm{m}^{3}\right)\end{array}$ & & & & \\
\hline 1 & IRD & 3,5 & 0,046 & 3,1 & 0,04 & 3 & 0,039 & 3,4 & 0,044 & 32,8 & 3,28 & 0,427 & 0,042 \\
\hline 2 & $\begin{array}{l}\text { OK/ Kamar } \\
\text { Operasi }\end{array}$ & 5 & 0,065 & 5,1 & 0,066 & 5,3 & 0,069 & 4,9 & 0,064 & 51 & 5,1 & 0,663 & 0,066 \\
\hline 3 & $\begin{array}{c}\text { Bersalin/ } \\
\text { Kandungan }\end{array}$ & 4,4 & 0,057 & 4,6 & 0,06 & 4,6 & 0,06 & 4,5 & 0,059 & 46,4 & 4,64 & 0,603 & 0,06 \\
\hline 4 & Melati & 3,2 & 0,042 & 3,1 & 0,04 & 3,2 & 0,042 & 3 & 0,039 & 31,2 & 3,12 & 0,406 & 0,041 \\
\hline 5 & Anggrek & 2,7 & 0,035 & 2,6 & 0,034 & 2,4 & 0,031 & 2,4 & 0,031 & 24,7 & 2,47 & 0,321 & 0,032 \\
\hline 6 & Mawar & 3 & 0,039 & 3 & 0,039 & 2,9 & 0,038 & 3,1 & 0,04 & 30,8 & 3,08 & 0,4 & 0,04 \\
\hline 7 & Cendana & 0,2 & 0,003 & 0,25 & 0,003 & 0,25 & 0,003 & 0,2 & 0,003 & 2,45 & 0,25 & 0,032 & 0,003 \\
\hline 8 & Laboratorium & 0,8 & 0,01 & 0,9 & 0,011 & 1 & 0,013 & 1 & 0,013 & 9,6 & 0,96 & 0,124 & 0,012 \\
\hline 9 & ICCU & 1 & 0,013 & 0,8 & 0,01 & 1,1 & 0,014 & 0,9 & 0,011 & 9,2 & 0,92 & 0,119 & 0,012 \\
\hline 10 & Poli & 3,4 & 0,044 & 3,2 & 0,042 & 3,4 & 0,044 & 3 & 0,039 & 29,2 & 2,92 & 0,379 & 0,038 \\
\hline 11 & $\begin{array}{c}\text { Pusk Oro Oro } \\
\text { Ombo }\end{array}$ & 7,2 & 0,094 & 7,3 & 0,095 & 7,4 & 0,096 & 7,6 & 0,099 & 74,4 & 7,44 & 0,967 & 0,097 \\
\hline 12 & Pusk Tawang & 5 & 0,065 & 5,1 & 0,066 & 4,9 & 0,064 & 4,8 & 0,062 & 51 & 5,1 & 0,663 & 0,066 \\
\hline 13 & $\begin{array}{c}\text { Pusk } \\
\text { Banjarejo }\end{array}$ & 7,9 & 0,103 & 8 & 0,104 & 7,8 & 0,101 & 8 & 0,104 & 79,6 & 7,96 & 1,035 & 0,104 \\
\hline 14 & $\begin{array}{c}\text { Pusk } \\
\text { Demangan }\end{array}$ & 6 & 0,078 & 5,9 & 0,077 & 6,2 & 0,081 & 6,1 & 0,079 & 60,9 & 6,09 & 0,792 & 0,079 \\
\hline 15 & $\begin{array}{c}\text { Pusk } \\
\text { Manguharjo }\end{array}$ & 7,2 & 0,094 & 7,4 & 0,096 & 7,2 & 0,094 & 7,2 & 0,094 & 74 & 7,4 & 0,96 & 0,096 \\
\hline 16 & Pusk Patihan & 6,6 & 0,086 & 6,5 & 0,085 & 6,4 & 0,083 & 6,4 & 0,083 & 65,1 & 6,51 & 0,846 & 0,085 \\
\hline & JUMLAH & 67,1 & 0,872 & 66,9 & 0,869 & 67,1 & 0,872 & 66,5 & 0,864 & 675,3 & 67,5 & 8,779 & 0,0878 \\
\hline
\end{tabular}




\section{PEMBAHASAN}

\section{Analisa Data}

Berat dan Volume Timbulan sampah

Berdasarkan hasil pengukuran berat sampah medis tiap ruangan menunjukkan bahwa ratarata berat sampah medis selama 10 ( sepuluh ) hari pengamatan berturut-turut terdapat sebanyak 67,5 kg/hari.

Sedangkan pada tabel IV.1 terlihat besarnya volume timbulan sampah medis yang dihasilkan dari tiap-tiap ruangan dengan menggunakan perhitungan berdasarkan rekomendasi APHA $\left(77,745 \mathrm{~kg} / \mathrm{m}^{3}\right)$

Tabel 5. Hasil Pemusnahan, Waktu Yang Digunakan Dan Suhu Incenerator Dalam Pemusnahan Sampah Medis Setiap Hari Selama 10 Hari

\begin{tabular}{|c|c|c|c|c|c|c|c|c|c|c|}
\hline \multirow[t]{2}{*}{ Kegiatan } & \multicolumn{10}{|c|}{ Ha ri } \\
\hline & 1 & 2 & 3 & 4 & 5 & 6 & 7 & 8 & 9 & 10 \\
\hline Sebelum & 68,3 & 67,8 & 68,5 & 67,6 & 68,2 & 67,4 & 67,1 & 66,9 & 67,1 & 66,5 \\
\hline $\begin{array}{l}\text { Pemusnahan } \\
\text { (kg) }\end{array}$ & & & & & & & & & & \\
\hline Sisa & 26 & 25,6 & 26,4 & 25,3 & 26,2 & 25,1 & 24,7 & 23,8 & 24,3 & 23,4 \\
\hline $\begin{array}{l}\text { Pemusnahan } \\
\text { (kg) }\end{array}$ & & & & & & & & & & \\
\hline$\%$ Sisa & 38,1 & 37,8 & 38,5 & 37,4 & 38,4 & 37,2 & 36,8 & 35,6 & 36,2 & 35,2 \\
\hline Pemusnahan & & & & & & & & & & \\
\hline Suhu Bakar $\left({ }^{\circ} \mathbf{C}\right)$ & 800 & 800 & 800 & 800 & 800 & 800 & 800 & 800 & 800 & 800 \\
\hline Waktu ( jam ) & 2 & 2 & 2 & 2 & 2 & 2 & 2 & 2 & 2 & 2 \\
\hline
\end{tabular}

\section{Efektif Penggunaan Incenerator.}

Dari perhitungan volume dengan menggunakan rekomendasi APHA tersebut, selanjutnya dipakai untuk mengetahui besarnya volume timbulan sampaj medis yang dimusnahkan setiap hari selama10 hari yaitu sebagai berikut
a. Pemusnahan $\mathrm{I}=0,887$
b. Pemusnahan II $=0,881$
c. Pemiusnahan III $=0,891$
d. Pemusnahan IV $=0,879$
e. Pemusnahan V $=0,887$
f. Pemusnahan VI $=0,876$
g. Pemusnahan VII $=0,872$

Tabel 6. Perbandingan Antara Volume Sampah Medis dan Volume Incenerator

\begin{tabular}{ccccc}
\hline $\begin{array}{c}\text { Pembakaran } \\
\text { hari ke }\end{array}$ & $\begin{array}{l}\text { Vol.Sampah } \\
\text { Medis }\left(\mathbf{m}^{\mathbf{3}}\right)\end{array}$ & $\begin{array}{l}\text { Volume } \\
\text { Incenerator } \\
\left(\mathbf{m}^{\mathbf{3}}\right)\end{array}$ & $\begin{array}{l}\text { Jml. } \\
\text { Kelebihan } \\
\left(\mathbf{m}^{\mathbf{3}}\right)\end{array}$ & Keterangan \\
\hline $\mathbf{1}$ & 0,887 & 0,700 & 0,187 & Kurang efektif \\
$\mathbf{2}$ & 0,881 & 0,700 & 0,181 & Kurang efektif \\
$\mathbf{3}$ & 0,891 & 0,700 & 0,191 & Kurang efektif \\
$\mathbf{4}$ & 0,879 & 0,700 & 0,179 & Kurang efektif \\
$\mathbf{5}$ & 0,887 & 0,700 & 0,187 & Kurang efektif \\
$\mathbf{6}$ & 0,876 & 0,700 & 0,176 & Kurang efektif \\
$\mathbf{7}$ & 0,872 & 0,700 & 0,172 & Kurang efektif \\
$\mathbf{8}$ & 0,869 & 0,700 & 0,169 & Kurang efektif \\
$\mathbf{9}$ & 0,872 & 0,700 & 0,172 & Kurang efektif \\
$\mathbf{1 0}$ & 0,864 & 0,700 & 0,164 & Kurang efektif \\
Jumlah & $\mathbf{8 , 7 7 8}$ & & & \\
\hline
\end{tabular}

Sumber : Hasil penelitian h. Pemusnahan VIII $=0,869$

i. Pemusnahan IX $=0,872$

j. Pemusnahan $X=0,864$

Berdasarkan data tersebut di atas, bahwa ratarata volume sampah medis yang dimusnahkan setiap hari adalah $0,878 \mathrm{~m}^{3} /$ hari.

Dengan volume incenerator yang dipersyaratkan oleh pihak pabrik $0,7 \mathrm{~m}^{3}$ dan waktu pembakaran 1 ( satu ) kali/ hari selama 2 jam, dengan jam kerja 8 jam/ hari, menunjukkan bahwa sampah medis tersebut semuanya dipaksakan 1 kali pembakaran yang menyebabkan kurang efektif, seperti yang tertera di tabel 6: 
Berdasarkan tabel 6 diatas, menunjukkan bahwa dengan hanya 1 kali pembakaran dengan waktu 2 jam dari 8 jam kerja setiap hari, ternyata semuanya menunjukkan kurang efektif, karena melebihi kapasitas efektif yaitu $0,7 \mathrm{~m} 3$ dengan toleransi $0,1 \mathrm{~m} 3$.

Untuk waktu yang diperlukan dalam pengoperasian incenerator dalam sehari adalah : $8,778 \mathrm{~m} 3: 10 \mathrm{kali}=0,878 \mathrm{~m} 3$ dalam sekali bakar $0,7 \mathrm{~m} 3: 0,878 \mathrm{~m} 3$ dalam sekali bakar $=$ 0,797 m3 ( kelebihan )

Dengan rata-rata volume sampah medis 0,878 $\mathrm{m} 3 /$ hari. Volume sampah medis selama 1 tahun $=360 \times 0,878 \mathrm{~m} 3=316,08 \mathrm{~m} 3 /$ tahun, bisa dimusnahkan di Incenerator setiap hari secara bertahap.

Dengan perhitungan tersebut di atas bahwa terdapat kelebihan sebesar 0,797 m3, maka seharusnya pembakaran dilakukan 2 kali dalam sehari atau dilakukan secara bertahap.

Dengan padatnya sampah medis yang ada dalam incenerator, dapat menyebabkan kurangnya jumlah oksigen dan mengakibatkan tidak terjadinya reaksi yang sempurna pada semua sampah medis (udara dipasok lewat lubang angin dengan kipas "blower").

Sisa Pembakaran dan Efisiensi Pembakaran Dengan pemusnahan sampah medis seperti yang tertera di tabel 5 rata-rata sampah medis yang dihasilkan setiap hari 67,5 $\mathrm{kg} /$ hari, dengan suhu bakar $800^{\circ} \mathrm{C}$, lama waktu yang digunakan 2 jam dengan menghasilkan sisa pemusnahan yang bila dirata-rata hanya mempunyai kemampuann reduksi sebesar 62,88 ( tabel 5 ).

Dengan pembakaran yang mempunyai suhu $800^{\circ} \mathrm{C}$ dan lama waktu tinggal 2 jam sekali digunakan, ternyata belum mampu menghancurkan sampah medis yang berupa benda tajam dan ampul sehingg masih memerlukan penanganan/ perlakuan khusus untuk sisa hasil pembakaran tersebut.

Sisa jaringan tubuh habis operasi dan plasenta bekas kelahiran bayi dalam penanganannya diberi disinfectan terlebih dahulu baru dikubur pada tempat yang telah disediakan, dimana lahan dari RSUD Kota ABC masih sangat memungkinkan untuk tindakan tersebut

\section{SIMPULAN}

Jumlah volume yang efektif untuk pembakaran pada incinerator di RSUD kota Madiun adalah 0,7 m3, jika melebihi volume tersebut maka incinerator tidak efektif, karena tidak semua sampah medis terbakar sempurna.

Penggunaaan incinerator yang baik dan efektif adalah dengan volume tidak lebih dari 0,7 m3, karena apabila volume sampah medis yang dimusnahkan melebihi volume yang dipersyaratkan,maka mengakibatkan kurangnya oksigen dalam tungku bakar, dimana oksigen tersebut berfungsi untuk membantu proses pembakaran di dalam tungku incenerator, sehingga pembakaran tersebut tidaklah efektif.

Sisa pembakaran sampah medis yang berupa ampul, vial dan jarum suntik tidak dapat dimusnahkan menjadi abu sehingga masih memerlukan penanganan khusus.

\section{UCAPAN TERIMA KASIH}

Terimakasih saya ucapkan kepada Tuhan Yang Maha Esa atas berkat yang diberikan kepada saya. Terimakasih kepada semua pihak yang telah membantu baik material maupun non material demi mendukung saya dalam penelitian ini

\section{DAFTAR PUSTAKA}

Cappucino, J.G. \& Sherman, N.,2001, "Microbiology - a laboratory manual", Addison Wesley, Reading.HarleyPrescott, Laboratory Exercises Microbiology, Fifth Edition,2002, The McGraw Hill Companies.

DepKes RI, 1997, Pedoman Sanitasi Rumah Sakit di Jakarta. Jakarta, DirJen PPM \& PLP - Yan Medik

Harley-Prescott, Laboratory Exercises Microbiology, Fifth Edition,2002, The McGraw Hill Companies.

Jarwanto dan Pangestu Subagyo,MBA, Statistik Induktif Edisi 4, BPFE Jogjakarta.

Lucia W Muslimin, Mikrobiologi lingkungan, Jakarta, DirJen Diktidepdikbud, 1995

Peraturan Menteri Kesehatan nomor 986 tahun 1992 tentang Persyaratan Kesehatan Lingkungan Rumah Sakit, DirJen PPM \& PLP Departemen Kesehatan RI 
Peraturan Menteri Negara Lingkungan Hidup nomor 30 tahun 2009 tentang Tata Laksana Perizinan dan Pengawasan Pengelolaan Limbah Bahan Berbahaya dan Beracun serta Pengawasan Pemulihan Akibat Pencemaran Limbah Bahan Berbahaya dan Beracun oleh Pemerintah Daerah

Rahayu Dwi Utami, D.G Okayadnya dan M. Mirwan, Meningkatkan Kinerja Incenerator Pada Pemusnahan Limbah Medis RSUD Dr. Soetomo Surabaya, Jurnal Ilmiah Teknik Lingkungan Vol.7 No.2, Program Studi Teknik Lingkungan, Fakultas Teknik Sipil dan Perencanaan, Universitas Pembangunan
Reinhardt, P A \& J.G. Gordon, 1995, Pengelolaan Limbah Menular dan Limbah Medik (Buku I\&II) Jakarta, AKL DepKes RI.

Tchobanoglous,G.H.Theisen, and S.Vigil (1993) "Integrated Solid Waste Management", McGraw-Hill, New York Undang-Undang Republik Indonesia nomor 32 tahun 2009 tentang: Pengelolaan Lingkungan Hidup, Jakarta, Biro Bina Lingkungan Hidup 